\title{
POLA KERUKUNAN MELAYU DAN TIONGHOA DI KOTA SINGKAWANG
}

\author{
Amalia Irfani \\ Fakultas Ushuluddin, Adab dan Dakwah (FUAD) \\ Intitut Agama Islam Negeri (IAIN) Pontianak \\ Email: amaliadachlan82@gmail.com
}

\begin{abstract}
This paper briefly describes how the pattern of harmony between Malay and Chinese communities in Singkawang City, two major ethnicities and became political authorities alternately in the city; through sociological communication studies. The result of the study it was found that the harmony of the people in Singkawang City can be categorized as dynamic and harmonious. Tolerance is so high applied in the life of society and politics by the people. In terms of social relations, there are no significant differences between these two ethnicities, almost the same can be said to be no difference at all, there is no element of legal discrimination for every ethnic group in here. Constraints that arise in their social life are the use of language, as well as the Chinese community which seems more closed and more restricting the association with other ethnic groups.
\end{abstract}

(Tulisan ini secara singkat memaparkan tentang bagaimana Pola Kerukunan masyarakat Melayu dan Tionghoa di Kota Singkawang, dua etnis besar dan menjadi penguasa politis secara bergantian di Kota tersebut; melalui kajian komunikasi-sosiologis. Hasil kajian sosiologis atas Kerukunan masyarakat di Kota Singkawang dapat dikategorikan dinamis dan harmonis. Toleransi yang begitu tinggi diaplikasikan dalam kehidupan bermasyarakat maupun politik oleh masyarakat kota Singkawang. Kemudian, dari sisi hubungan sosial, tidak ada perbedaan yang signifikan antar dua etnis ini, hampir sama bahkan dapat dikatakan tidak ada perbedaan sama sekali, di mana tidak ada unsur diskriminasi hukum bagi setiap etnis di Kota Singkawang. Kendala yang muncul di kehidupan bermasyarakat mereka adalah yaitu pengunaan dalam berbahasa, seperti halnya masyarakat Tionghoa yang nampak lebih tertutup dan lebih membatasi pergaulan dengan etnis lain).

Key Words: Pola, Kerukunan Etnis, Kota Singkawang

\section{PENDAHULUAN}

Hal terpenting dalam kehidupan bermasyarakat, berbangsa dan bernegara adalah terbinanya kerukunan di dalam masyarakat itu sendiri. Kerukunan idealnya bersifat timbal balik, dimana satu sama lain tetap menjunjung tinggi perbedaan yang tampak. Perbedaan seringkali memunculkan masalah jika tidak adanya pengertian antar masyarakat yang memang sudah sangat berbeda. Perbedaan agama seringkali ditengarai sebagai alasan timbulnya konflik antar masyarakat diakhiri dengan kerusuhan rasial.

Begitu pentingnya membina kerukunan khususnya kerukunan umat 
beragama pemerintah melakukan sosialisasi dan implementasi Peraturan Bersama Menteri Agama dan Menteri dan Menteri Dalam Negeri Nomor 9 dan 8 Tahun 2006 tentang Pedoman Pelaksanaan Tugas Kepala Daerah Dalam Pemeliharaan Kerukunan Umat Beragama, Pemberdayaan Forum Kerukunan Umat Beragama, dan Pendirian Ibadah. Hal ini mengindikasikan bahwa memelihara kerukunan merupakan hal penting mengukuhkan semangat cinta negara.

Salah satu wilayah Indonesia yang masyarakatnya memiliki kerukunan terkategori baik adalah Kota Singkawang Provinsi Kalimantan Barat. Tidak seperti kota atau kabupaten lainnya yang ada di Kalimantan Barat, Singkawang relatif aman dengan gesekan berujung kerusuhan. Padahal, Kota Singkawang memiliki pluralitas agama dan etnis, namun memiliki toleransi tinggi terhadap perbedaan agama maupun etnis. Misalnya pada saat terjadi kerusuhan di Sambas Kalimantan Barat Tahun 1999 dan Sampit Kalimantan Tengah tahun 2001, kerusuhan menjalar ke berbagai kota, kabupaten terdekat, namun tidak sampai membuat Kota Singkawang juga tersulut api kemarahan. Bahkan banyak masyarakat etnis Madura yang mendapatkan perlindungan di Singkawang.
Pluralitas masyarakat Kota Singkawang, terutama dalam agama dan budaya ternyata tidak menimbulkan persoalan bagi kerukunan umat beragama. Hal ini disebabkan interaksi sosial masyarakat Kota Singkawang cenderung bersifat assosiatif. Di Kota Singkawang, Hubungan antar agama dapat terkategori harmonis disebabkan : pertama: Konflik yang terjadi sebelum ini bukanlah konflik agama. Yang terjadi sebelum ini muncul karena adanya kepentingan politik dan golongan, ekonomi, dan kepentingan pribadi yang merembet pada upaya membawa persoalan ini pada tataran agama, etnis dan budaya. selain itu kuatnya motivasi untuk terus hidup rukun dengan kelompok lain merupakan sinyal mengenal kesadaran masing masing untuk terus menjaga kerukunan. Dialog yang terbangun antar agama selama ini cukup intensif. Kesadaran ini mendorong tumbuhnya kerukunan antar umat beragama ${ }^{1}$.

Masyarakat Singkawang adalah masyarakat yang terdiri atas berbagai kelompok suku bangsa dan agama. Secara historis, masyarakat Singkawang mampu mempertahankan harmoni antar agama.

\footnotetext{
1 Mursyid Ali. Pemetaan kerukunan kehidupan beragama di berbagai daerah di Indonesia, Jakarta: Departemen Agama RI, Badan Litbang dan Diklat, Puslitbang Kehidupan Keagamaan, 2009, hlm. 59.
} 
Model interaksi sosial yang bersifat asosiatif tampaknya potensial terjadi dan berhasil dikembangkan secara turun temurun oleh masyarakat Kota Singkawang khususnya etnis Melayu dan Tionghoa.

Berdasarkan paradigma fungsional struktural masyarakat diasumsikan sebagai sistem organik yang memiliki hubungan antar bagiannya untuk mempertahankan masyarakat. Interaksi sosial di dalam masyarakat Singkawang dikembangkan melalui interaksi di dalam lingkup keluarga, lingkungan sekitar, aktifitas ekonomi, para pimpinan agama, dan hubungan di dalam lingkup budaya dan tradisi. Meskipun demikian, hubungan antar unsur masyarakat masih kosmopolitan, dan masih ada anggota masyarakat yang kurang aktif mengembangkan keberagaman. Etnis Tionghoa dan Melayu merupakan tampilan dari proses interaksi masyarakat Kota Singkawang yang terkategori harmonis. Sejak resmi menjadi wilayah Kota tahun 2001, Singkawang di pimpin bergantian oleh etnis Melayu dan Tionghoa. Tahun 2001-2007 Awang Ishak, 2007-2012 Hasan Karman, 2012-2017 Awang Ishak, sekarang 2017-2022 Tjhai Chui Mie.

Atas dasar pemikiran tersebut, tulisan ini menjadi kajian penting, sebagai sebuah kajian Studi Agama-Agama di
Indonesia khususnya di Kalimantan Barat. Keunikan Kota Singkawang salah satunya adalah kota yang masih tetap mempertahankan identitas budaya dan keragaman selain banyaknya wisata alam menambah eksotisme khazanah alam Singkawang, sehingga Kalimantan Barat lebih dikenal masyarakat dunia.

\section{Kajian Pustaka}

1. Pola Kerukunan Asosiatif

Di wikipedia.com, Pola dapat diartikan bentuk atau model (atau, lebih abstrak, suatu set peraturan) yang bisa dipakai untuk membuat atau untuk menghasilkan suatu atau bagian dari sesuatu, khususnya jika yang ditimbulkan cukup mencapai suatu sejenis untuk pola dasar yang dapat ditunjukan atau terlihat. Pola terdiri atas 2 (dua) makna 1. Sistem; cara kerja dan 2. Bentuk (struktur) yang tetap.

Proses sosial asosiatif adalah proses sosial yang di dalam realitas sosial anggota-anggota masyarakatnya dalam keadaan harmoni yang mengarah pada pola-pola kerjasama. Harmoni sosial ini menciptakan kondisi sosial yang teratur atau disebut social order ${ }^{2}$. Proses sosial asosiatif terbagi atas tiga macam, kerjasama (co-operation),

2 Elly M. Setiadi. \& Usman Kolip. Pengantar Sosiologi. Bandung: Kencana Prenada Media Grup, hlm. 77. 
akomodasi (accomodation), dan asimilasi (asimilation). Secara garis besar dapat dipahami bahwa ketiga hal tesebut dapat terjadi ketika masyarakat di suatu tempat dapat hidup berdampingan atau rukun. Rukun menurut para ahli sosial adalah hasil akhir proses sosial yang bersifat dinamis.

Dalam bahasa Indonesia rukun dapat didefiniskan dalam 2 bentuk: 1 . Rukun (nominal), berarti: Sesuatu yang harus di penuhi untuk sahnya pekerjaan, seperti tidak sahnya manusia dalam sembahyang yang tidak cukup syarat, dan rukunnya asas, yang berarti dasar atau sendi: semuanya terlaksana dengan baik tidak menyimpang dari rukunnya agama. 2. Rukun (ajektif) berarti: Baik dan damai tidak bertentangan: hendaknya kita hidup rukun dengan tetangga, bersatu hati, sepakat. Merukunkan berarti: mendamaikan menjadikan bersatu hati. Kerukunan berarti: perihal hidup rukun; rasa rukun; kesepakatan: kerukunan hidup bersama.

Kerukunan berarti sepakat dalam perbedaan-perbedaan yang ada dan menjadikan perbedaan-perbedaan itu sebagai titik tolak untuk membina kehidupan sosial yang saling pengertian serta menerima dengan ketulusan hati yang penuh ke ikhlasan. Kerukunan merupakan kondisi dan proses tercipta dan terpeliharannya pola-pola interaksi yang beragam diantara unitunit (unsur/sub sistem) yang otonom. Kerukunan mencerminkan hubungan timbal balik yang ditandai oleh sikap saling menerima, saling mempercayai, saling menghormati dan menghargai, serta sikap saling memaknai kebersamaan. Dalam pengertian seharihari kata rukun dan kerukunan adalah damai dan perdamaian. Dengan pengertian ini jelas, bahwa kata kerukunan hanya dipergunakan dan berlaku dalam dunia pergaulan.

Kerukunan antar umat beragama bukan berarti menyatukan agamaagama yang ada dan melebur kepada satu totalitas (sinkretisme agama) dengan menjadikan agama-agama yang ada itu sebagai mazhab dari agama totalitas itu, melainkan sebagai cara atau sarana untuk mempertemukan, mengatur hubungan luar antara orang yang tidak seagama atau antara golongan umat beragama dalam kehidupan sosial kemasyarakatan. Jadi dapat disimpulkan bahwa kerukunan ialah hidup damai dan tentram saling toleransi antara masyarakat yang beragama sama maupun berbeda, kesediaan mereka untuk menerima adanya perbedaan keyakinan dengan 
orang atau kelompok lain, membiarkan orang lain untuk mengamalkan ajaran yang diyakini oleh masing-masing masyarakat, dan kemampuan untuk menerima perbedaan.

Berdasarkan Peraturan Menteri

No. 9 Tahun 2006 Pasal 1 ayat, kerukunan umat beragama adalah keadaan hubungan sesama umat beragama yang dilandasi toleransi, saling pengertian, saling menghormati, menghargai kesetaraan dalam pengamalan ajaran agamanya dan kerjasama dalam kehidupan bermasyarakat, berbangsa dan bernegara di dalam Negara Kesatuan Republik Indonesia berdasarkan Pancasila dan Undang-Undang Dasar Negara Republik Indonesia Tahun 1945.

Kerukunan adalah istilah yang dipenuhi oleh muatan makna "baik" dan "damai". Intinya, hidup bersama dalam masyarakat dengan "kesatuan hati" dan "bersepakat" untuk tidak menciptakan perselisihan atau pertengkaran. Hal ini sesuai dengan sila pertama Pancasila yaitu Ketuhanan Yang Maha Esa. Kerukunan juga bermakna sangat dalam sebab adalah sesuatu yang ideal dan didambakan oleh masyarakat. Kerukunan akan menciptakan suasana persaudaraan dan kebersamaan antar semua orang terdapat perbedaan mencolok, suku, agama, ras dan golongan.

Menurut Ghazali Ghazali (2005) kerukunan mengandung pengertian kondisi sosial hubungan antar umat beragama. Proses "rukun" adalah upaya penyadaran dalam beragama dapat dilakukan melalui upaya penyamaan visi, pemahaman, dan kesadaran terhadap eksistensi agama-agama, yaitu setiap agama secara esensial memiliki nilai-nilai universal yang dapat diterima oleh tiap-tiap pihak yang berbeda keyakinan. Melarang berbuat jahat dan mengharuskan berbuat baik adalah salah satu nilai universal yang diajarkan oleh semua agama.

$$
\text { Menurut Irwansyah }
$$

kerukunan adalah istilah yang dipenuhi oleh muatan makna "baik" dan “damai". Intinya, hidup bersama dalam masyarakat dengan "kesatuan hati" dan "bersepakat" untuk tidak menciptakan perselisihan dan pertengkaran. Asyari Nur (2008) menyebutkan kerukunan umat beragama adalah merupakan bagian dari kerukunan nasional. Ia menjadi inti dari kedamaian, ketentraman, dan keharmonisan dalam masyarakat. Kerukunan umat beragama adalah keadaan hubungan sesama umat beragama yang dilandasi toleransi, 
saling pengertian, saling menghormati, menghargai kesetaraan dalam pengamalan ajaran agamanya dan kerjasama dalam kehidupan bermasyarakat, berbangsa dan bernegara di dalam Negara Kesatuan Republik Indonesia berdasarkan Pancasila dan Undang-Undang Dasar 1945.

Dari kedua definisi diatas, maka Pola Kerukunan dapat didefiniskan, sebagai sistem, cara kerja atau bentuk dalam upaya membangun, menciptakan keharmonisan dalam masyarakat dengan tidak melihat perbedaan sehingga tercipta keseimbangan sosial. Terdapat tiga istilah yang sering digunakan untuk menggambarkan masyarakat yang beragam, baik secara agama, ras, bahasa, dan budaya, yakni : pluralitas (plurality), keragamaan (diversity), dan multikultural ( multikult ural ). Meskipun ketiganya sama-sama mengacu pada ketidaktunggalan, tetapi pada dasarnya masing-masing tidak merepresentasikan hal yang sama. Konsep pluralitas mengandaikan adanya hal-hal yang lebih dari satu.

Kerukunan hakikatnya adalah sebuah bentuk sosialisasi yang damai dan tercipta berkat adanya toleransi agama, dan budaya. Toleransi secara umum dipahami sebagai suatu sikap saling pengertian dan menghargai tanpa adanya diskriminasi dalam hal apapun. Kerukunan dalam masyarakat yang multikultural adalah kunci utama yang sangat penting di jaga dan dipertahankan untuk mencapai sebuah kesejahteraan hidup belahan bumi manapun. Seperti yang kita ketahui, Indonesia contohnya memiliki keragaman yang begitu banyak. Walaupun mayoritas penduduk Indonesia beragama Islam, ada beberapa agama lain yang juga dianut penduduk ini. Kristen, Katolik, Hindu, Budha dan Konghucu (Keppres No.6/2000 dan SK Menteri Agama Nomor MA/12/2006 sebagai pengganti Keppres No.6/2000). Perbedaan yang mencolok tersebut meinisiasi pemerintah untuk senantiasa mampu menjaga perbedaan yang tampak menjadi kekuatan melalui program Tri Kerukunan.

Pemerintah sendiri telah menyadari resistensi konflik antar umat beragama. Berbagai kebijakan pemerintah telah diterbitkan buat memperbaiki keadaan. Berbagai rambu peraturan telah disahkan agar meminimalisir bentrokan-bentrokan kepentingan antar umat beragama Seluruh peraturan pemerintah yang membahas tentang kerukunan antar 
umat beragama di Indonesia. Mencakup pada empat pokok masalah, yakni sebagai berikut.
a. Pendirian Rumah Ibadah.
b. Penyiaran Agama.
c. Bantuan Keagamaan dari Luar Negeri.
d. Tenaga Asing Bidang Keagamaan.

\section{Konsep Tri Kerukunan}

Tri kerukunan umat beragama adalah salah satu program pemerintah dalam rangka menjaga keutuhan Indonesia .bertujuan agar masyarakat Indonesia dapat menghayati dalam kebersamaan, dalam perbedaan. Tujuan utama dicanangkannya Tri Kerukunan Umat Beragama di Indonesia adalah agar masyarakat Indonesia bisa hidup dalam kebersamaan, sekalipun banyak perbedaan. Konsep ini dirumuskan dengan teliti dan bijak agar tidak terjadi pengekangan atau pengurangan hak-hak manusia dalam menjalankan kewajiban dari ajaran-ajaran agama yang diyakininya. Pada gilirannya, dengan terciptanya tri kerukunan itu akan lebih memantapkan stabilitas nasional dan memperkokoh persatuan dan kesatuan bangsa ${ }^{3}$.

\footnotetext{
3 Saputera, Agus. 2008. Kebijakan dan Strategi Kerukunan Umat Beragama di Indonesia. (online) (diakses tanggal 09 September 2016), hlm. 4.
}

Konsep ini merupakan ide dari Menteri Agama Indonesia ke-13 HA. Alamsyah Ratu Perwiranegara yang akhirnya dirumuskan dengan teliti dan bijak dengan tujuan agar tak terjadi pengekangan atau pengurangan hak-hak manusia dalam menjalankan kewajiban dari ajaran-ajaran agama yang diyakininya. Tri kerukunan ini meliputi tiga kerukunan, yaitu: Kerukunan intern umat beragama, Kerukunan antar umat beragama, dan Kerukunan antara umat beragama dan pemerintah.

Pertama: Kerukunan Intern Umat Beragama. Perbedaan pandangan dalam satu agama dapat melahirkan konflik di dalam tubuh suatu agama itu sendiri. Disparitas madzhab ialah salah satu disparitas yang nampak dan nyata. Kemudian lahir pula disparitas ormas keagamaan. Walaupun satu aqidah, yakni aqidah Islam, disparitas sumber penafsiran, penghayatan, kajian, pendekatan terhadap Al-Quran dan AsSunnah terbukti mampu mendisharmoniskan intern umat beragama. Konsep ukhuwwah islamiyah misalnya merupakan salah satu wahana agar tak terjadi ketegangan intern umat Islam yang menyebabkan peristiwa konflik. Konsep pertama ini mengupayakan berbagai cara agar tak saling klaim kebenaran. Menghindari permusuhan 
sebab disparitas madzhab dalam Islam. Semuanya buat menciptakan kehidupan beragama nan tenteram, rukun, dan penuh kebersamaan.

Konsep kedua dari tri kerukunan memiliki pengertian kehidupan beragama yang tentram antar masyarakat yang berbeda agama dan keyakinan. Tidak terjadi sikap saling curiga mencurigai dan selalu menghormati agama masing-masing. Berbagai kebijakan dilakukan oleh pemerintah, agar tak terjadi saling mengganggu umat beragama lainnya. Semaksimal mungkin menghindari kesamaan konflik sebab disparitas agama. Semua lapisan masyarakat bersama-sama menciptakan suasana hayati yang rukun dan damai di Negara Republik Indonesia.

Ketiga: Kerukunan Antara Umat Beragama dan Pemerintah. Pemerintah ikut andil dalam menciptakan suasana tentram, termasuk kerukunan antara umat beragama dengan pemerintah sendiri. Semua umat beragama yang diwakili para pemuka dari tiap-tiap agama bisa sinergis dengan pemerintah. Bekerjasama dan bermitra dengan pemerintah buat menciptakan stabilitas persatuan dan kesatuan bangsa. Trikerukunan umat beragama diharapkan menjadi menjadi salah satu solusi agar terciptanya kehidupan umat beragama nan damai, penuh kebersamaan, bersikap toleran, saling menghormati dan menghargai dalam perbedaan.

\section{Kota Singkawang dan Masyarakatnya yang Toleransi}

Kota Singkawang memiliki banyak julukan, salah satunya adalah Kota Singkawang dijuluki dengan julukan kota Amoi. Penduduk Kota Singkawang $48 \%$ adalah Tionghoa, dan selebihnya adalah Melayu, Dayak, dan Madura. Masyarakat Tionghoa disini mayoritas bermata pencaharian sebagai pedagang atau pengusaha. pusat kota singkawang banyak dihuni oleh masyarakat Tionghoa. Mungkin inilah alasan kenapa kota ini dijuluki dengan julukan Kota Amoi. Kota Singkawang juga dikenal dengan sebutan kota Seribu Kuil, karena di setiap sudut kota ini dapat ditemui banyak bangunan vihara atau lebih dikenal sebagai kelenteng atau pekong. Bangunan ini memiliki arsitektur yang khas, didominasi warna merah dan hiasan liong.

Masyarakat yang tinggal di Kota Singkawang hidup berdampingan saling membantu satu sama lain, seperti banyak masyarakat Melayu yang bekerja dengan masyarakat Tionghoa, karna memang masyarakat Tionghoa yang bermata 
pencaharian sebagai seorang pedagang dan pengusaha banyak memerlukan karyawan, jadi banyaklah peluang pekerjaan yang dibuka oleh masyarakat Tionghoa, ini menjadi keuntungan bagi masyarakat Melayu yang tidak mempunyai pekerjaan. Masyarakat Melayu juga banyak membantu masyarakat Tionghoa dalam menjalankan usahanya, seperti ada yang menjadi karyawan, konsumen, dan sebagai tempat mereka membeli sumber pokok dari apa yang mereka jual, seperti halnya beras dari petani melayu,dan hasil laut dari nelayan melayu. hidup mereka berdampingan dan saling membantu.

Dari segi sosial Singkawang juga bisa di katakan sebagai kota bertoleransi tinggi, karena mereka hidup berdampingan, mereka saling hormat menghormati antar agama, bahkan rumah ibadah mereka bisa saling berdampingan dengan jarak yang dekat, seperti halnya masjid raya Singkawang dengan Vihara yang terletak di dekat pusat kota Singkawang, tidak pernah ada konflik atau pertikaian yang serius antar umat beragama ini, mereka bisa hidup rukun tanpa ada perselisihan sedikit pun, dan tak jarang juga biasanya masyarakat muslim melakukan penggalangan dana untuk masyarakat kurang mampu atau untuk membantu kaum muslim yang membutuhkan bantuan pengobatan dan tidak mampu untuk membayar pengobatan, tidak jarang masyarakat Tionghoa juga ikut menyumbang dengan tanpa pandang bulu, walaupun beda agama mereka tetap membantu atau ikut menyumbang, dan bahkan terkadang banyak masyarakat Tionghoa yng menyumbang dengan nominal yang tidak sedikit.

Kota Singkawang juga memiliki julukan sebagai Kota Tasbih, karena dari arah Bengkayang ada gerbang untuk memasuki Kota Singkawang ada sebuah plang yang mulai usang tetapi tetap berdiri kokoh, bertuliskan Selamat Datang di Singkawang Kota Tasbih, Kota Tasbih disini menempati posisi sebagai julukan singkatan, arti TASBIH disini bukan berarti menonjolkan umat Islam sebagai Agama yang mayoritas, tetapi Tasbih di sini hanya sebuah singkatan, yang tersusun dari kata kata $\mathrm{T}$ dari kata Tertib, A dari kata Aman, S dari kata Sehat, B dari kata Bersih, I dari kata Indah, dan $\mathrm{H}$ dari kata harmonis, maka terbentuk lah kata Tasbih.

\section{Hubungan Masyarakat di Kota Singkawang}

Awalnya Singkawang merupakan sebuah desa bagian dari wilayah kesultanan Sambas, Nama Singkawang menurut versi Melayu diambil dari nama tanaman 'Tengkawang' yang terdapat di wilayah hutan tropis. Namun yang paling 
diyakini adalah versi bahasa Cina, Singkawang berasal dari kosa kata "San Keuw Jong" yang secara harfiah berarti Gunung Mulut Lautan, maksudnya suatu tempat yang terletak di kaki gunung menghadap ke laut. Awalnya Singkawang merupakan sebuah desa bagian dari wilayah kesultanan Sambas, Desa Singkawang sebagai tempat singgah para pedagang dan penambang emas dari Monterado.

Menurut cerita, Para penambang dan pedagang yang kebanyakan berasal dari negeri China, sebelum mereka menuju Monterado terlebih dahulu beristirahat di Singkawang, sedangkan para penambang emas di Monterado yang sudah lama sering beristirahat di Singkawang untuk melepas kepenatannya dan Singkawang juga sebagai tempat transit pengangkutan hasil tambang emas (serbuk emas). Waktu itu, mereka (orang Tionghoa) menyebut Singkawang dengan kata San Keuw Jong (Bahasa Hakka), mereka berasumsi dari sisi geografis bahwa Singkawang yang berbatasan langsung dengan laut Natuna serta terdapat pengunungan dan sungai, dimana airnya mengalir dari pegunungan melalui sungai sampai ke muara laut.

Melihat perkembangan Singkawang yang dinilai oleh mereka yang cukup menjanjikan, sehingga antara penambang tersebut beralih profesi ada yang menjadi petani dan pedagang di Kota Singkawang yang pada akhirnya para penambang tersebut tinggal dan menetap di Singkawang. Hingga sekarang melalui pendataan sensus penduduk, bahwa jumlah keseluruhan masyakat Tionghoa sekitar 42\%, sisanya adalah suku Melayu, Madura, dayak , dan suku pendatang lainnya ${ }^{4}$.

Pasca kemerdekaan wilayah Singkawang menjadi bagian dari Kabupaten Sambas bahkan menjadi lokasi ibukota kabupaten Sambas di Singkawang (UU No. 27 Tahun 1959) dengan status Kecamatan Singkawang. Pada tahun 1981 Kota ini menjadi Kota Administratif Singkawang (PP No. 49 Tahun 1981). Singkawang menjadi Daerah Otonom berdasarkan Undang-Undang Nomor: 12 Tahun 2001 tentang Pembentukan Kota Singkawang. Kehidupan masyarakat Kota Singkawang yang multietnis terdiri dari 3 (tiga) etnis terbesar yakni Tionghoa (Cina), Melayu dan Dayak ditambah suku-suku lainnya yang hidup secara berdampingan dan harmonis.

Dari fakta sejarah diatas, dapat dipahami bahwa ada kerukunan di Singkawang bersifat asosiatif yang selalu terpelihara di Kota Singkawang. Hubungan tersebut terpelihara secara turun temurun,

\footnotetext{
${ }^{4}$ Sensus Penduduk: 2014, dalam: http :
} //www.singkawang.us. 
berkelanjutan bahkan sudah seperti budaya untuk sebagian masyarakat asli Kota Singkawang.

Kota Singkawang termasuk kota kecil dengan luas 50.400 ha, yang dibagi menjadi 5 (lima) wilayah kecamatan meliputi 26 kelurahan. Nama Singkawang menurut versi Melayu diambil dari tanaman "Tengkawang" yang terdapat di wilayah hutan tropis. Namun, yang paling diyakini adalah versi bahasa Cina, Singkawang berasal dari kosakata "San Keuw Jong" yang secara harfiah berarti Gunung Mulut Lautan, maksudnya suatu tempat yang terletak di kaki gunung menghadap ke laut. Pasca kemerdekaan wilayah Singkawang menjadi bagian dari kabupaten dari Kabupaten Sambas, bahkan menjadi lokasi ibukota Kabupaten Sambas di Singkawang (UU No. 27 Tahun 1959), dengan status Kecamatan Singkawang. Singkawang menjadi daerah otonom berdasarkan Undang-Undang Nomor : 12 Tahun 2001 tentang pembentukan Kota Singkawang.

Aktivitas masyarakat Singkawang dalam memenuhi kebutuhan hidup didominasi di sektor perdagangan, dengan presentase hampir $90 \%$, selain itu etnis Tionghoa banyak juga yang bekerja di sektor lainnya seperti pertanian, perkebunan dan nelayan. Sedangkan, Etnis Melayu lebih banyak bergerak di pemerintahan menjadi pegawai negeri, petani, serta sebagian kecil berprofesi sebagai pedagang warung makan.

Di Singkawang, agama dan budaya mampu menjadi perekat kerukunan, namun jika tidak dikelola dengan baik berpotensi melemahkan kerukunan. Sikap toleransi atau interaksi akomodatif masyarakat Singkawang terkategori baik. Interaksi tersebut bersifat positif dan berkesinambungan.

Potensi kerukunan umat beragama di Singkawang adalah sebuah ranah sosial, tergolong dinamis dan harmonis. Keberagamaan di Kota Singkawang tidak saja dipertemukan dalam lintas iman, melainkan dalam lingkungan sosial. Kerukunan beragama tidak sampai menyentuh ranah teologis. Dari hasil observasi, wawancara didapat bahwa, perbedaan agama, budaya dan status sosial tidak menjadi sumber masalah yang mampu membuat interaksi sosial di keseharian berujung konflik. Kalaupun ada itu hanya bersifat momentum dan dapat diselesaikan dalam bentuk dialog yang difasilitasi oleh pemerintah melalui FKUB.

Upaya pemeliharaan kerukunan umat beragama di Kota Singkawang yang dilakukan oleh FKUB tahun 2007-2013 di antaranya:

1. Penyelesaian konflik Pawai Cap Go Meh dan Pawai Taruf 
2. Penyelesaian konflik Renovasi Gereja Stasi Santo Petrus di Jalan Bukit Tiga Kelurahan Roban Kecamatan Singkawang Tengah.

3. Penyelesaian konflik Tugu Naga di Jalan Niaga Kecamatan Singkawang Barat

4. Penyelesaian konflik/polemik pembangunan Pekong/Altar di Jalan Suhada Kelurahan Roban Kecamatan Singkawang Tengah

5. Menyelesaikan konflik Rumah Ibadah Gereja GPDI Kelurahan Sekip Lama dengan masyarakat sekitar, pada tanggal 10 Juni 2016, bertempat di Kantor Camat Singkawang Tengah

Sedangkan penyebab yang dideteksi dapat memicu konflik di Kota Singkawang adalah :

1. Ada beberapa oknum masyarakat/ organisasi masyarakat yang kurang menyadari, menghargai dan menghormati perbedaan.

2. Masih ada stereotipe yang tinggi, seperti pandangan Etnis Tionghoa mengenai Etnis Melayu khususnya agama Islam adalah agama yang keras, terlebih lagi organisasi masyarakat seperti FPI yang dalam pandangan mereka pembuat kerusakan.

3. Sensitivitas dari masyarakat Melayu yang menganggap orang tionghoa adalah orang yang berakal jahat (suka curang).

4. Masih ada etnosentris yang masih kuat di dalam diri masyarakat.

5. Kecemburuan sosial yang ada dalam diri masyarakat khususnya Melayu, yang merasa iri karena orang tionghoa yang menguasai pasar.

6. Masyarakat yang kurang setuju karena merasa tersinggung dengan anggapan bahwa kota singkawang adalah kota orang Tionghoa, dikarenakan ada gelar bahwa kota Singkawang adalah kota seribu kuil/klenteng.

\section{Pola Kerukunan Melayu dan Tionghoa di Kota Singkawang}

umat beragama di Kalimantan Barat mengarah pada simbolisasi adat dengan agama, tidak terkecuali yang ada di Kota Singkawang. Identifikasi pemeluk agama terkait dengan identifikasi etnis dengan sistem adatnya. Seperti pemeluk Islam diidentikkan dengan etnis Melayu, meskipun itu berasal dari suku dayak. Bahkan anggota suku Dayak yang memeluk Islam dianggap telah keluar dari anggota suku dengan menanggalkan identitas budayanya. Kekuatan pengaruh suku yang begitu kuat dalam masyarakat di Kalimantan Barat seperti pengukukan identitas etnis dalam bentuk organisasi 
massa misalnya seperti Dewan Adat Dayak (DAD), Majelis Adat Budaya Melayu (MABM), dan Majelis Adat Budaya Tionghoa (MABT), cenderung lebih tampak bersentuhan pada politik praktis. Tetapi ini tidak terlalu tampak di Kota Singkawang, masyarakat masih kental Padahal organisasi massa tersebut selain sebagai identitas etnis juga melekat simbol-simbol agama.

Dominasi adat dalam kehidupan masyarakat sebetulnya bisa menjadi modal sosial menciptakan kerukunan umat beragama. Akan tetapi adat justru lebih berperan dalam ranah politik. Akibatnya pola kerukunan umat beragama di Kalimantan Barat tidak membumi. Dalam pola kerukunan di Kalimantan Barat tidak ditemukan bentuk kerukunan yang terwadahi secara kuat dalam kultur budaya. Akibatnya, pola kerukunan antar umat beragama masih berada pada dataran kulit, hanya sebatas untuk menjaga kestabilan sosial dan ekonomi. Akibat dari pola sosial seperti itu, bentuk kerukunan yang ada hanya sebatas kerukunan sebagai warga masyarakat. Bentuk kerukunan yang ada yaitu saling mengunjungi ketika ada perhelatan perkawinan, kelahiran atau kematian. Bentuk kerukunan yang lebih luas, yaitu ketika terjadi acara berkaitan dengan peringatan hari-hari besar nasional seperti peringatan hari kemerdekaan RI, upacara robok-robok, upacara cap gomeh, dan upacara naik dangau. Keterlibatan anggota agama lain dalam acara itu, hanya sebatas tamu undangan, penonton atau panitia pendukung.

Berdasarkan hasil temuan dan analisis data di atas dapat disimpulkan beberapa hal penting terkait dengan hasil penelitian ini sebagai berikut:

1. Kerukunan masyarakat Melayu dan Tionghoa di Kota Singkawang.

Kerukunan masyarakat di Kota Singkawang dapat dikategorikan dinamis dan harmonis. Gesekan di masyarakat yang terjadi tidak membuat hubungan diantara mereka khususnya etnis Melayu dan Tionghoa menjadi renggang dan berujung konflik.

Perbedaan pun bukan menjadi alasan untuk bekerjasama, saling membantu dan bertoleransi. Toleransi yang begitu tinggi diaplikasikan dalam kehidupan bermasyarakat maupun politik oleh masyarakat kota Singkawang. Dari sisi hubungan sosial, tidak ada perbedaan yang signifikan antar dua etnis ini, hampir sama bahkan dapat dikatakan tidak ada perbedaan sama sekali. Di mana tidak ada unsur diskriminasi hukuman bagi setiap etnis di Kota Singkawang.

Kendala yang muncul di kehidupan bermasyarakat mereka 
adalah yaitu pengunaan dalam berbahasa, seperti halnya masyarakat Tionghoa yang nampak lebih tertutup dan lebih membatasi pergaulan dengan etnis lain. Hal ini disebabkan minimnya pengetahuan dengan bahasa pemersatu yaitu bahasa Indonesia. Banyak masyarakat etnis Tionghoa khususnya yang sudah berusia lanjut yang tidak bisa menggunakan bahasa Indonesia secara baik dan benar, bahkan ada beberapa yang sama sekali tidak mengerti dan menggunakan bahasa Indonesia. Hal ini menyebabkan sulitnya komunikasi untuk berkomunikasi dengan etnis lain. Mereka hanya bisa menggunakan bahasa etnisnya saja. Tetapi untuk masyarakat etnis Tionghoa yang masih muda dapat berkomunikasi dengan baik dengan etnis lain dikarenakan dapat menggunakan bahasa indonesia dengan baik dan benar.

2. Faktor-faktor yang mempengaruhi kerukunan Melayu dan Tionghoa di Kota Pontianak

Kerukunan yang ada di Kota Singkawang dipengaruhi oleh banyak faktor. Faktor-faktor tersebut tidak serta merta melekat di masyarakat, tetapi didukung oleh pranata-pranata sosial atau sistem sosial yang ada pada masyarakat tersebut. Di Kota Singkawang, kerukunan di pengaruhi oleh peran sosial pemimpin di Pemerintahan dan tokoh masyarakat dalam membina dan meningkatkan toleransi antar masyarakat. Khusus untuk etnis Melayu dan Tionghoa, menurut hasil observasi dan wawancara didapat bahwa, persaudaraan erat salah satunya disebabkan kuatnya toleransi yang terbina dan terjaga secara turun temurun.

Secara turun temurun, toleransi yang ada di Kota Singkawang melekat melalui proses adaptasi, persamaan, dan perkawinan. Perkawinan merupakan alasan kuat sehingga hubungan perekatan menjadi lebih kuat, bertahan lama dan harmonis. Kesadaran untuk selalu menjaga harmonisasi antara Melayu dan Tionghoa tercermin jelas pada saat interaksi di kehidupan keseharian. Keunikan masyarakat Melayu dan Tionghoa pada perpaduan antara keteguhan dan sekaligus kelenturan. Mereka merupakan masyarakat yang teguh memegang adat istiadat nenek moyang mereka yang sudah ratusan tahun. Hal ini terwujud dalam pelaksanaan upacara sekitar siklus kehidupan (perkawinan, kehamilan, dan kematian) dan upacara hari-hari besar agama (Idul Fitri, Idul 
Adha, Tahun Baru Imlek, Cap Go Meh). Pada sisi yang lain, ma syarakat Kota Singkawang merupakan masyarakat yang lentur. Hal ini ditunjukkan dengan pembauran dua kebudayaan yang disertai dengan hilangnya ciri khas kebudayaan asli sehingga membentuk kebudayaan baru (asimilasi), dan suatu proses sosial yang timbul manakala suatu kelompok manusia dengan kebudayaan tertentu dihadapkan dengan unsur dari suatu kebudayaan asing (akulturasi) dengan masyarakat dan sekaligus kebudayaan setempat.

3. Pola Kerukunan Asosiatif Melayu dan Tionghoa di Kota Singkawang

Secara umum pola interaksi antar umat beragama di Kalimantan Barat mengarah pada simbolisasi adat dengan agama, tidak terkecuali yang ada di Kota Singkawang. Identifikasi pemeluk agama terkait dengan identifikasi etnis dengan sistem adatnya. Seperti pemeluk Islam diidentikkan dengan etnis Melayu, meskipun itu berasal dari suku dayak. Bahkan anggota suku Dayak yang memeluk Islam dianggap telah keluar dari anggota suku dengan menanggalkan identitas budayanya.

Kekuatan pengaruh suku yang begitu kuat dalam masyarakat di
Kalimantan Barat seperti pengukukan identitas etnis dalam bentuk organisasi massa misalnya seperti Dewan Adat Dayak (DAD), Majelis Adat Budaya Melayu (MABM), dan Majelis Adat Budaya Tionghoa (MABT), cenderung lebih tampak bersentuhan pada politik praktis. Tetapi ini tidak terlalu tampak di Kota Singkawang, masyarakat masih kental Padahal organisasi massa tersebut selain sebagai identitas etnis juga melekat simbol-simbol agama.

Dari paparan diatas, dapat dilihat bahwa Pola Kerukunan Etnis Melayu dan Tionghoa di Kota Singkawang merupakan reealitas yang nasionalisme sebagai perwujudan ketahanan negara, mulai pudar dan cenderung hilang jika tidak kembali dimunculkan dan dipelajari oleh generasi muda bangsa. Pendidikan menjadi solusi utama dan pertama. Namun ada beberapa hal menurut peneliti yang bisa membantu untuk menjaga semangat kerukunan bangsa, diantaranya adalah :

Diberikan ruang untuk berdialoq dalam ruang budaya tanpa ada unsur paksaan dari pihak lain. Dengan dialog, kerukunan beragama akan menjadi nyata melalui peningkatan pemahaman ajaran agama pada masing-masing pengikut/umat beragama; menjunjung tinggi perbedaan dan keanekaragaman pemahaman keagamaan; mengesampingkan pikiran- 
pikiran yang menganggap pendekatan budaya tidak relevan. Lewat dialog itu pula akan tumbuh kedewasaan beragama, yakni kesanggupan untuk menghormati perbedaan keyakinan dalam beragama.

\section{KESIMPULAN}

Pola Kerukunan masyarakat Melayu dan Tionghoa di Kota Singkawang, melalui kajian komunikasi-sosiologis, diperoleh beberapa kesimpulan: Pertama, kerukunan masyarakat di Kota Singkawang dapat dikategorikan dinamis dan harmonis. Kedua, tidak ada perbedaan yang signifikan antar dua etnis ini, hampir sama bahkan dapat dikatakan tidak ada perbedaan sama sekali.

\section{DAFTAR PUSTAKA}

Elly M. Setiadi. \& Usman Kolip. Pengantar Sosiologi. Bandung : Kencana Prenada Media Grup.

http : //www.singkawang.us

Mulyana, Edi, dan Rakhmat Jalaluddin. Editor. 1996. Komunikasi Antarbudaya, Bandung: PT. Remaja Rosdakarya.

Mursyid Ali. Pemetaan kerukunan kehidupan beragama di berbagai daerah di Indonesia, Jakarta: Departemen Agama RI, Badan Litbang dan Diklat, Puslitbang Kehidupan Keagamaan, 2009.

Purwasito, Andrik. 2003. Komunikasi Multikultural, Surakarta: Muhammadiyah University Press.

Saputera, Agus. 2008. Kebijakan dan Strategi Kerukunan Umat Beragama di Indonesia. (online) (diakses tanggal 09 September 2016). 